\title{
TIME wound assessment tool: interobserver agreement
}

\section{Ferramenta TIME para avaliação de feridas: concordância interobservador}

TIME para evaluación de heridas: acuerdo de interobserver

\author{
Nazareno Ferreira Lopes Coutinho Júnior 1,*, Sandra Marina Gonçalves Bezerra', Nayra Ferreira \\ Lima Castelo Branco', Marianne Rocha Duarte de Carvalho ${ }^{1}$, Kerson Rocha Júnior ${ }^{1}$, Luís Felipe \\ Oliveira Ferreira², Elyrose Sousa Brito Rocha ${ }^{1}$
}

ORCID IDs

Coutinho Júnior NFL (D) https://orcid.org/0000-0003-2110-3642

Bezerra SMG (D) https://orcid.org/0000-0003-3890-5887

Branco NFLC (D) http://orcid.org/0000-0002-2569-7647

Carvalho MRD (D) https://orcid.org/0000-0001-8479-7376

Rocha Júnior K (D) https://orcid.org/0000-0003-0204-2784

Ferreira LFO (D) https://orcid.org/0000-0002-2982-894X

Rocha ESB (D) https://orcid.org/0000-0002-7722-6564

\begin{abstract}
HOW TO CITE
Coutinho Júnior NFL; Bezerra SMG; Branco NFLC; Carvalho MRD; Rocha Júnior K; Ferreira LFO; Rocha ESB. Ferramenta TIME para avaliação de feridas: concordância interobservador. ESTIMA, Braz. J. Enterostomal Ther., 18: e1720, 2020. https:// doi.org/10.30886/estima.v18.875_IN
\end{abstract}

\begin{abstract}
Objective: To verify interobserver agreement on wound evaluation using the TIME tool. Methods: Exploratory, nonexperimental study with cross-sectional design and quantitative approach. The population consisted of undergraduate students from the eighth, ninth and tenth periods of the baccalaureate nursing course, enrolled in the second semester of 2018. An expositive-dialogued class about the TIME tool was prepared and presented to the participants. The students were directed to the teaching hospital for socialization of clinical cases and individual evaluation of ten skin lesions with different clinical characteristics in the hospitalized patient, using the TIME tool. To identify the agreement between the students, when using the TIME tool, the Kappa agreement coefficient was used. Results: The number of undergraduates who were attending the ninth period of the course (80\%), female (80\%), and average age (23.2 years) prevailed. Considering the Kappa classification, there was excellence ( $\mathrm{K}=1.0)$ in interobserver agreement in all stages of the TIME tool. Conclusion: It is inferred that the TIME tool ensures agreement in the evaluation of wounds among nursing undergraduates who are attending the last course periods, and may contribute to improving the quality of nursing care.
\end{abstract}

DESCRIPTORS: Nursing assessment; Wounds and injuries; Benchmarking; Enterostomal therapy; Nursing.

\footnotetext{
1. Universidade Estadual do Piauí - Centro de Ciências da Saúde - Teresina/PI -Brazil.

2. Universidade Federal do Piauí - Parnaíba/PI -Brazil.

*Correspondence authore: nflcj@hotmail.com

Received: Abr. 18, 2018 | Accepted: Jul. 21, 2020
} 


\section{RESUMO}

Objetivo: Verificar a concordância interobservador sobre avaliação de feridas utilizando a ferramenta TIME. Métodos: Estudo de caráter exploratório, não experimental com delineamento transversal e abordagem quantitativa. A população foi constituída por graduandos do oitavo, nono e décimo período do curso de bacharelado em enfermagem, matriculados no segundo semestre do ano de 2018 . Aula expositiva-dialogada sobre a ferramenta TIME foi elaborada e posta aos participantes. Os graduandos foram direcionados ao hospital de ensino para socialização de casos clínicos e avaliação individual de dez lesões de pele com características clínicas diferentes, no paciente hospitalizado utilizando a ferramenta TIME. Para identificar a concordância entre os discentes na utilização da ferramenta TIME, foi utilizado o coeficiente de concordância Kappa. Resultados: Prevaleceu o número de graduandos que estavam cursando o nono período do curso (80\%), sexo feminino (80\%), idade média (23,2 anos). Obteve-se que, considerando a classificação Kappa, houve excelência $(K=1,0)$ na concordância interobservador em todas as etapas da ferramenta TIME. Conclusão: Infere-se que a ferramenta TIME assegura concordância na avaliação de feridas entre graduandos de enfermagem que estão cursando os últimos períodos de curso, podendo contribuir com a melhoria da qualidade do cuidado de enfermagem.

DESCRITORES: Avaliação em enfermage; Ferimentos e lesões; Benchmarking; Estomaterapia; Enfermagem.

\section{RESUMEN}

Objetivo: verificar el acuerdo interobservador sobre la evaluación de heridas utilizando la herramienta TIME. Métodos: estudio exploratorio no experimental con diseño transversal y enfoque cuantitativo. La población consistió en estudiantes de pregrado de los períodos octavo, noveno y décimo del curso de enfermería de bachillerato, inscritos en el segundo semestre de 2018. Se preparó y presentó a los participantes una conferencia de diálogo expositivo sobre la herramienta TIME. Los estudiantes fueron dirigidos al hospital universitario para la socialización de casos clínicos y la evaluación individual de diez lesiones cutáneas con diferentes características clínicas en el paciente hospitalizado, utilizando la herramienta TIME. Para identificar el acuerdo entre los estudiantes, utilizando la herramienta TIME, se utilizó el Coeficiente de Acuerdo de Kappa. Resultados: prevaleció el número de estudiantes universitarios que asistían al noveno período del curso (80\%), mujeres (80\%) y edad promedio (23,2 años). Teniendo en cuenta la clasificación de Kappa, hubo excelencia $(K=1.0)$ en el acuerdo interobservador en todas las etapas de la herramienta TIME. Conclusión: se infiere que la herramienta TIME garantiza un acuerdo en la evaluación de heridas entre los estudiantes de pregrado de enfermería que asisten a los últimos períodos del curso y puede contribuir a mejorar la calidad de la atención de enfermería.

DESCRIPTORES: Evaluación en enfermería; Heridas y traumatismos; Benchmarking; Estomaterapia; Enfermería.

\section{INTRODUCTION}

The nursing care to the client with a wound integrates the daily routine of the team in all levels of health care, in the public or private network, demanding from the professional nurse scientific knowledge and ability in face of the most diverse aspects related to prevention, evaluation and treatment of an injury. It is observed that this professional has been seeking to broaden his knowledge in the area of wound treatment ${ }^{1}$.

Thus, the role of the nurse includes the anamnesis and general physical examination, the evaluation of the lesion, the choice of treatment and follow-up, and the evaluation of the results obtained with the established treatment. Currently, there are numerous technologies and products available for the prevention and treatment of wounds. In order to determine the proper conduct, a reliable evaluation of the wound is necessary, with the aim of raising as many factors as possible that may interfere in the healing process and, consequently, in the client's recovery. Recently, the Brazilian Federal Council of Nursing approved the Resolution 567/2018, which regulates the nursing team's performance in the care of patients with wounds, expanding the performance of this professional in the area in question ${ }^{2-4}$.

Nevertheless, a study carried out in a hospital in Paraíba showed that nurses have limitations in knowledge and practical fragilities to evaluate the lesions and the patient, and indicate the coverage and type of dressing to be used in the control of signs and symptoms of lesions ${ }^{5}$.

Thus, a wound is considered a rupture of the tegument, mucosa or any part of the body that can be caused by a chemical, biological or physical agent. The TIME tool has the objective of being implemented in wound care, guaranteeing the evaluation and allowing the establishment of interventions aiming at the promotion of healing, considering the evaluated parameters. It is a dynamic model formed by four important parameters for the wound bed preparation. These parameters are associated with the obstacles present in the wound bed that make healing difficult. The " $\mathrm{T}$ " refers to the identification of the tissue present in the wound bed, the "I" shows the signs of inflammation or infection that may exist, the " $\mathrm{M}$ " relates to the management of exudate and the "E" describes the characteristics of the wound edges ${ }^{6-8}$. 
An evaluation tool can be considered simple and easy to apply; however, the process to evaluate an injury can lead to divergent interpretations. An erroneous evaluation can have serious consequences, such as the determination of inappropriate conduct, causing complications and delaying the healing process 9 .

Therefore, the importance of this study is justified by the need to evaluate and discuss the process of wound evaluation, especially on the effectiveness and quality of this practice. It is considered relevant to discuss the agreement in the evaluation of wounds among future nursing professionals, because the concern with the quality of care must be present in undergraduate courses, essentially in the last periods of the course, when the graduate will be increasingly closer to the professional exercise.

\section{OBJECTIVE}

To verify the interobserver agreement on wound evaluation using the TIME tool.

\section{METHODS}

Exploratory, nonexperimental study with transversal design and quantitative approach. Developed in the facilities of a higher education institution (HEI), public and located in the state of Piauí, as well as in a general, public and teaching hospital, a reference in the network of the single health system at medium and high-complexity level ${ }^{10}$.

The population consisted of eighth $(\mathrm{n}=11)$, ninth $(n=20)$ and tenth $(n=14)$ year graduates of the HEI bachelor's degree in nursing, enrolled in the second half of $2018(n=45)$. Inclusion criteria were considered: graduating over 18 years old, regularly enrolled in the eighth, ninth or tenth period of the baccalaureate nursing course, having studied and obtained approval in the subjects Nursing Fundamentals, Field Work IV and Nursing in Enterostomal Therapy, offered in the fourth and seventh period of the course, respectively, and who accepted to participate in the study after clarification. Participants who, for some reason, were unable to attend and participate in any stage of data collection were excluded. After applying these criteria, the sample consisted of ten participants, two of whom were in the eighth period and eight in the ninth.

The data were collected in November 2018. To this end, the researchers sent a formal invitation via e-mail to the classes, scheduling the day and time for the clarifications, at the HEI facilities. For the application of the first data collection instrument regarding the characterization of the sample, date and time have been programmed with the groups involved. Moreover, a two-hour lecture on the applicability of the TIME tool and its dimension was prepared and given to the participants of the study. The lecture was conducted by a professional $\mathrm{PhD}$ in nursing, with clinical experience in the evaluation area.

After the above-mentioned steps, the nursing students were directed to the teaching hospital for the socialization of clinical cases and individual evaluation of ten skin lesions with different clinical characteristics in the hospitalized patient, using the TIME tool. Aiming at the reliability and impartiality of the results, the clinical cases were selected by a professional $\mathrm{PhD}$ in nursing and with extensive clinical experience in wound evaluation. The role of this professional was also to establish the "gold standard" for the evaluation of the lesions involved in the study, using the TIME tool, and also to judge the evaluation performed by the students. In this way, the TIME tool filled in by the participants was submitted to appreciation, being classified each TIME dimension, in "incorrect evaluation" and "correct evaluation".

The collected data was typed in Microsoft Excel software in double worksheet for validation. To identify the agreement between the students when using the TIME tool, the kappa coefficient was used, a useful test to expose the concordance between two or more judges in a nominal or ordinal evaluation of the same sample and classify the respective values as “inconsistent" $(<0)$,"poor" (0), "weak" (0 to 0.20$)$, "considerable" (0.21 to 0.40$)$, "moderate" (0.41 to 0.60$)$, "substantial" (0.61 to 0.80 ) and "excellent" (0.81 to 1$)^{11-13}$.

The research observed the ethical and legal aspects for research with human beings according to the recommendations of Resolution No. 466/12 of the National Health Council of the Brazilian Ministry of Health. The study was approved by the Research Ethics Committee of Universidade Estadual do Piauí (UESPI), under the opinion of No.2,903,039 and the Research Ethics Committee on Human Beings of Hospital Getúlio Vargas, under the opinion of No. 2,935,595.

\section{RESULTS}

The number of undergraduates that were attending the ninth period of the nursing course (80\%), female (80\%) and average age of 23.2 years prevailed. 
Table 1 shows that there were $100 \%$ accuracy in all lesions evaluated regarding the type of tissue present in the wound bed, with the exception of lesion IX, with $80 \%$ for this item of the instrument. About the first and second lesion, the same table reports that there were 70 and $60 \%$ of errors when evaluating the exudate characteristics, respectively. In the third lesion there were $60 \%$ accuracy for the characteristics described on the exudate and for the evaluation of the edges of the mentioned wound.

In the fourth lesion there were $90 \%$ accuracy for the identification of signs of inflammation/infection, $60 \%$ accuracy for the characteristics of the exudate and for the analysis of the edges. The table also shows that there were $90 \%$ errors about the evaluation of the edges in the fifth wound. In the sixth lesion there were 100\% accuracy for the signs of inflammation/infection and $70 \%$ of errors for exudate description. In the seventh lesion there were 100\% accuracy about the signs of inflammation/infection and $90 \%$ of errors for exudate description. When the eighth lesion was evaluated, there were $100 \%$ accuratecy for signs of inflammation/infection and $60 \%$ of errors when the characteristics of the exudate were evaluated. When the ninth lesion was evaluated, there were $100 \%$ accuracy in the identification of signs of inflammation/infection; regarding the type and quantity of exudate, there were $50 \%$ of errors. Finally, when considering the evaluation of the tenth lesion, there were $100 \%$ accuracy for exudate management; as for the signs of inflammation/infection, there were $50 \%$ of errors.

Table 1. Lesion assessment performed by study participants, according to TIME tool and gold standard established by experienced professional. Teresina, Piauí, Brazil, $2018(n=10)$.

\begin{tabular}{|c|c|c|c|c|c|c|}
\hline \multicolumn{7}{|c|}{ LESION I } \\
\hline \multirow{2}{*}{ Variable } & \multicolumn{3}{|c|}{ Accuracy } & \multicolumn{3}{|c|}{ Errors } \\
\hline & $n$ & $\%$ & Mean & $\mathrm{n}$ & $\%$ & Mean \\
\hline$T$ & 10 & 100 & 1.0 & 0 & 0 & 0.0 \\
\hline 1 & 7 & 70 & 0.7 & 3 & 30 & 0.3 \\
\hline M & 3 & 30 & 0.3 & 7 & 70 & 0.7 \\
\hline$E$ & 6 & 60 & 0.6 & 4 & 40 & 0.4 \\
\hline \multicolumn{7}{|c|}{ LESION II } \\
\hline \multirow{2}{*}{ Variable } & \multicolumn{3}{|c|}{ Accuracy } & \multicolumn{3}{|c|}{ Errors } \\
\hline & $n$ & $\%$ & Mean & $n$ & $\%$ & Mean \\
\hline$T$ & 10 & 100 & 1.0 & 0 & 0 & 0.0 \\
\hline 1 & 9 & 90 & 0.9 & 1 & 10 & 0.1 \\
\hline M & 4 & 40 & 0.4 & 6 & 60 & 0.6 \\
\hline E & 8 & 80 & 0.8 & 2 & 20 & 0.2 \\
\hline \multicolumn{7}{|c|}{ LESION III } \\
\hline \multirow{2}{*}{ Variable } & \multicolumn{3}{|c|}{ Accuracy } & \multicolumn{3}{|c|}{ Errors } \\
\hline & $\mathrm{n}$ & $\%$ & Mean & $\mathrm{n}$ & $\%$ & Mean \\
\hline $\mathrm{T}$ & 10 & 100 & 1.0 & 0 & 0 & 0.0 \\
\hline 1 & 9 & 90 & 0.9 & 1 & 10 & 0.1 \\
\hline M & 6 & 60 & 0.6 & 4 & 40 & 0.4 \\
\hline E & 6 & 60 & 0.6 & 4 & 40 & 0.4 \\
\hline \multicolumn{7}{|c|}{ LESION IV } \\
\hline \multirow{2}{*}{ Variable } & \multicolumn{3}{|c|}{ Accuracy } & \multicolumn{3}{|c|}{ Errors } \\
\hline & $n$ & $\%$ & Mean & $\mathrm{n}$ & $\%$ & Mean \\
\hline $\mathrm{T}$ & 10 & 100 & 1.0 & 0 & 0 & 0.0 \\
\hline 1 & 9 & 90 & 0.9 & 1 & 10 & 0.1 \\
\hline M & 6 & 60 & 0.6 & 4 & 40 & 0.4 \\
\hline $\mathrm{E}$ & 6 & 60 & 0.6 & 4 & 40 & 0.4 \\
\hline
\end{tabular}


Table 1. Continuation...

\begin{tabular}{|c|c|c|c|c|c|c|}
\hline \multicolumn{7}{|c|}{ LESION V } \\
\hline \multirow{2}{*}{ Variable } & \multicolumn{3}{|c|}{ Accuracy } & \multicolumn{3}{|c|}{ Errors } \\
\hline & $\mathrm{n}$ & $\%$ & Mean & $\mathrm{n}$ & $\%$ & Mean \\
\hline $\mathrm{T}$ & 10 & 100 & 1.0 & 0 & 0 & 0.0 \\
\hline I & 9 & 90 & 0.9 & 1 & 10 & 0.1 \\
\hline$M$ & 5 & 50 & 0.5 & 5 & 50 & 0.5 \\
\hline E & 1 & 10 & 0.1 & 9 & 90 & 0.9 \\
\hline \multicolumn{7}{|c|}{ LESION VI } \\
\hline \multirow{2}{*}{ Variable } & \multicolumn{3}{|c|}{ Accuracy } & \multicolumn{3}{|c|}{ Errors } \\
\hline & $n$ & $\%$ & Mean & $\mathrm{n}$ & $\%$ & Mean \\
\hline$T$ & 10 & 100 & 1.0 & 0 & 0 & 0.0 \\
\hline I & 10 & 100 & 1.0 & 0 & 0 & 0.0 \\
\hline$M$ & 3 & 30 & 0.3 & 7 & 70 & 0.7 \\
\hline E & 6 & 60 & 0.6 & 4 & 40 & 0.4 \\
\hline \multicolumn{7}{|c|}{ LESION VII } \\
\hline \multirow{2}{*}{ Variable } & \multicolumn{3}{|c|}{ Accuracy } & \multicolumn{3}{|c|}{ Errors } \\
\hline & $\mathrm{n}$ & $\%$ & Mean & $\mathrm{n}$ & $\%$ & Mean \\
\hline $\mathrm{T}$ & 10 & 100 & 1.0 & 0 & 0 & 0.0 \\
\hline 1 & 10 & 100 & 1.0 & 0 & 0 & 0.0 \\
\hline$M$ & 1 & 10 & 0.1 & 9 & 90 & 0.9 \\
\hline E & 7 & 70 & 0.7 & 3 & 30 & 0.3 \\
\hline \multicolumn{7}{|c|}{ LESION VIII } \\
\hline \multirow{2}{*}{ Variable } & \multicolumn{3}{|c|}{ Accuracy } & \multicolumn{3}{|c|}{ Errors } \\
\hline & $\mathrm{n}$ & $\%$ & Mean & $\mathrm{n}$ & $\%$ & Mean \\
\hline $\mathrm{T}$ & 10 & 100 & 1.0 & 0 & 0 & 0.0 \\
\hline 1 & 10 & 100 & 1.0 & 0 & 0 & 0.0 \\
\hline$M$ & 4 & 40 & 0.4 & 6 & 60 & 0.6 \\
\hline$E$ & 5 & 50 & 0.5 & 5 & 50 & 0.5 \\
\hline \multicolumn{7}{|c|}{ LESION IX } \\
\hline \multirow{2}{*}{ Variable } & \multicolumn{3}{|c|}{ Accuracy } & \multicolumn{3}{|c|}{ Errors } \\
\hline & $n$ & $\%$ & Mean & $n$ & $\%$ & Mean \\
\hline$T_{-}^{\top}$ & 8 & 80 & 0.8 & 2 & 20 & 0.2 \\
\hline 1 & 10 & 100 & 1.0 & 0 & 0 & 0.0 \\
\hline$M$ & 5 & 50 & 0.5 & 5 & 50 & 0.5 \\
\hline E & 8 & 80 & 0.8 & 2 & 20 & 0.2 \\
\hline \multicolumn{7}{|c|}{ LESION $\mathrm{X}$} \\
\hline \multirow{2}{*}{ Variable } & \multicolumn{3}{|c|}{ Accuracy } & \multicolumn{3}{|c|}{ Errors } \\
\hline & $\mathrm{n}$ & $\%$ & Mean & $\mathrm{n}$ & $\%$ & Mean \\
\hline $\mathrm{T}$ & 10 & 100 & 1.0 & 0 & 0 & 0.0 \\
\hline 1 & 5 & 50 & 0.5 & 5 & 50 & 0.5 \\
\hline$M$ & 10 & 100 & 1.0 & 0 & 0 & 0.0 \\
\hline $\mathrm{E}$ & 7 & 70 & 0.7 & 3 & 30 & 0.3 \\
\hline
\end{tabular}

Source: Direct research. 
Table 2 shows the kappa coefficient of agreement, according to the evaluation performed by the participants in the ten lesions that were object of this study, using the TIME tool and considering the gold standard previously established. Considering the kappa classification, there was excellence $(\mathrm{K}=1.0)$ in interobserver agreement in all steps of the TIME tool.

Table 2. General agreement between study participants in the evaluation of lesions according to the kappa coefficient. Teresina, Piauí, Brazil, $2018(n=10)$.

\begin{tabular}{|c|c|c|}
\hline \multirow{2}{*}{ Variable } & \multicolumn{2}{|c|}{ Agreement } \\
\hline & $\mathrm{K}^{*}$ & Classification \\
\hline $\mathrm{T}$ & 1.00 & Excellent \\
\hline 1 & 1.00 & Excellent \\
\hline M & 1.00 & Excellent \\
\hline$E$ & 1.00 & Excellent \\
\hline
\end{tabular}

*Kappa coefficient of agreement.

Source: Direct research.

\section{DISCUSSION}

In this study, the participants who attended the ninth period of the undergraduate course in nursing prevailed. This result is associated with the difficulty encountered to adjust equal schedules for all participants during the stages of data collection, given the limitations related to academic commitments, since this course is full-time.

The female gender was highlighted with a considerable percentage, which corroborates the characteristics of the profession desired by the participants. A cross-sectional study conducted with a universe of 1.8 million nursing professionals, whose objective was to draw the profile of the nursing team in Brazil, showed that, in the whole country, $86.2 \%(357,551)$ of nursing professionals belong to the female sex. In Piauí, the number is $84.6 \%(5,794)^{14}$.

Regarding the type of tissue present in the wound bed, the study showed that there was excellence $(K=1.0)$ in interobserver agreement, which is in line with a study conducted in outpatient clinics of five hospitals in the greater São Paulo, together with patients with chronic leg ulcers, which aimed to test the reliability among clinical nurses and enterostomal therapists on the pressure ulcer scale for healing (PUSH) tool, in its version adapted for the Portuguese language. The survey showed that there was total agreement $(K=1.0)$ between the responses of all observers regarding the evaluation of the appearance of the wound bed. In addition, it is important to note that the results of this study show that, besides the excellent agreement, the participants obtained from 80 to $100 \%$ accuracy in this TIME tool item $^{15}$.

Regarding the signs of infection/inflammation evaluated, kappa showed excellence $(K=1.0)$. However, a study was found in the literature with students from the last period of the undergraduate nursing course at a public institution in Paraná, Brazil, that showed a lack of identification of signs of inflammation/infection and understanding about the difference between contamination and wound colonization. In the same study, regarding the peculiarities of a lesion with signs of inflammation/infection, most researchers did not mention hyperthermia (96\%), edema (70\%), local heat (66.7\%) and pain (60\%)16. In fact, although the participants in this study obtained excellent agreement, the percentage of accuracy for this item varied, in most of the lesions, between 80 to $100 \%$, obtaining only $50 \%$ in one of the lesions.

Descriptive, exploratory research, with quantitative analysis, conducted at Hospital de Base de Ribeirão Preto, Brazil, which aimed to evaluate the agreement between the care nurses regarding the evaluation and classification of risk for pressure injury in patients in intensive care units, showed that the subscale "humidity" was the one with the lowest agreement between nurses and the researcher, classified as poor $(\mathrm{K}=0.0)$ in two intensive care units and no degree of agreement in the third unit $(\mathrm{K}=-0.04)^{17}$.

Although the research mentioned above is the object of a separate study from the present investigation, these results point to the subjectivity that involves the evaluations of the item "humidity" by the nurse. This fact draws attention 
to the probable need for greater emphasis on this point, specifically during the formation and improvement of these professionals.

Moreover, experts in the field emphasize that exudate is an essential component to be observed and controlled for healing and that, in addition to volume, its appearance and composition must be considered, since there is evidence that the composition of the chronic wound fluid is as important as its quantity. In comparison with the acute wound, it has been shown that chronic wound exudate inhibits the growth of fibroblasts, necessary for the deposition and organization of collagen, and that it has increased levels of proinflammatory cytokines, oxygen free radicals and proteases, prolonging the inflammatory stage of wound healing. In agreement with these observations, the percentage of accuracy of the participants of this study for item "M" of the TIME tool, varied from 10 to $100 \%$ in the lesions evaluated ${ }^{18}$.

When assessing the properties of the edges of the lesions, kappa showed excellent agreement $(K=1.0)$. No scientific evidence was found in the literature about the agreement or disagreement in the item "edges".

It is worth mentioning that, in the educational institution studied, the subject Nursing in Enterostomal Therapy composes the mandatory curricular grid of the graduation course in Nursing since 2017, being offered in the seventh period, with a workload of 45 hours per semester. Given the relevance of the knowledge acquired in the discipline, it is understood that the results obtained in this study are directly associated with this training.

Limitations were found for conducting the survey, related to the difficulty in reconciling schedules and days for the population to be present at times of data collection, which hampered the sample size, the lack of studies in the literature that address the process of wound evaluation, especially on the use of the TIME tool, and interobserver agreement, being found with prevalence articles addressing only the theme of treatment deferred.
Therefore, it is considered relevant to continue the discussion about the wound evaluation process, especially about the effectiveness and quality of this practice present in the routine of the nurse professional. Thus, new studies should be carried out with the aim of expanding the sample of participants and increasing the number of wounds to be assessed, as well as including not only undergraduate students, but also professionals and specialists in the area in question.

\section{CONCLUSION}

The study was able, through the methodology used, to answer its objective in a satisfactory way. The interobserver agreement on wound evaluation, a question of this research, proved to be "excellent", considering the Kappa values ( $\mathrm{K}=$ 1.0) assigned to each dimension of the TIME tool.

Therefore, although the percentages of accuracy of this study still demonstrate some difficulties in the process of wound evaluation, on the part of the participants, it is inferred that the TIME tool assures agreement in the wound evaluation, among nursing graduates who are attending the last periods of course, being able to contribute to the improvement of the quality of nursing care.

\section{AUTHOR'S CONTRIBUTION}

Conceptualization, Rocha ESB; Methodology, Rocha ESB; Investigation, Coutinho Júnior NFL; Ferreira LFO and Rocha ESB; Formal Analysis, Carvalho MRD; Bezerra SMG and Branco NFLC; Data Curation, Rocha Júnior K; Writing - Original Draft, Rocha ESB and Coutinho Júnior NFL; Writing - Review and Editing, Rocha ESB; Coutinho Júnior NFL; Bezerra SMG and Branco NFLC; Supervision, Carvalho MRD and Rocha ESB; Project Administration, Rocha ESB.

\section{REFERÊNCIAS}

1. Campos MGCA, Sousa ATO, Vasconcelos JMB, Lucena SAP, Gomes SKA. Feridas complexas e estomias: aspectos preventivos e manejo clínico. João Pessoa: Ideia;2016.

2. Oliveira FP, Oliveira BGRB, Santana RF, Silva BP, Candido JSC. Classificações de intervenções e resultados de enfermagem em pacientes com feridas: mapeamento cruzado. Rev Gaúcha Enferm. 2016;37(2):e55033. https:// doi.org/10.1590/1983-1447.2016.02.55033

3. Squizatto RH, Braz RM, Lopes AO, Rafaldini BP, Almeida DB, Poletti NAA. Perfil dos usuários atendidos em ambulatório de cuidado com feridas. Cogitare Enferm. 2017;22(1):1-9. https://doi.org/10.5380/ce.v22i1.48472 
4. Brasil. Conselho Federal de Enfermagem (COFEN). Resolução COFEN n.567/2018 de 7 de fevereiro de 2018. Regulamenta a atuação da equipe de enfermagem no cuidado aos pacientes com feridas. 2018. [Cited on 8 Abr 2018]. Available at: http://www.cofen.gov.br/resolucaocofen-no-567-2018_60340.htm

5. Agra G, Medeiros MVS, Brito DTF, Sousa ATO, Formiga NS, Costa MML. Conhecimento e prática de enfermeiros no cuidado a pacientes com feridas tumorais malignas. Rev Cuid. 2017;8(3):1849-62. https://doi.org/10.15649/cuidarte. v8i3.441

6. Aron S, Gamba MA. Preparo do leito da ferida e a história do TIME. ESTIMA, Braz J Enterostomal Ther. 2009;7(4):1.

7. Rocha DM, Bezerra SMG, Santos RR, Moreira L. Avaliação do leito da ferida e utilização da ferramenta TIME. In: Bezerra SMG, Rocha DM, Nogueira LT, organizadores. Protocolo de prevenção, avaliação e tratamento de lesões de pele do Município de Teresina. Teresina: EDUESPI; 2016. p.19-23.

8. Machado FS, Costa AEK, Pissaia LF, Beschorner CE, Moreschi C. Perspective of the nurse in front of nursing care in the treatment of wounds in hospitals. R Epidemiol Control Infec. 2017;7(3):134-9. https://doi.org/10.17058/reci.v7i3.8920

9. Bajay HM, Araújo IEM. Validação e confiabilidade de um instrumento de avaliação de feridas. Acta Paul Enferm.2006;19(3):290-5. https://doi.org/10.1590/S010321002006000300006

10. Brasil. Secretária de Estado da Saúde do Piauí. Hospital Getúlio Vargas: Referência para o Meio Norte do Brasil.
Quem somos. 2018. [Cited on 8 Abr 2018]. Available at: http://www.hgv.pi.gov.br/quem.php

11. Martins GA. Estatística geral e aplicada. Rio de Janeiro:Atlas; 2009.

12. Triola MF. Introdução à estatística. Rio de Janeiro: LTC; 2008.

13. Landis JR, Kock GG. The measurement of observer agreement for categorical data. Biometrics, 1977;33(1):15974. https://doi.org/10.2307/2529310

14. Conselho Federal de Enfermagem (COFEN). Pesquisa inédita traça perfil da enfermagem. 2018. [Cited on 5 Dez 2018]. Available at: http://www.cofen.gov.br/pesquisa-ineditatraca-perfil-da-enfermagem_31258.html

15. Santos VLCG, Sellmer D, Massulo MME. Inter rater reliability of Pressure Ulcer Scale for Healing (PUSH) in patients with chronic leg ulcers.Rev Latino-Am Enfermagem. 2007;15(3):391-6. https://doi.org/10.1590/S0104-11692007000300005

16. Baratieri T, Sangaleti CT, Trincaus MR. Conhecimento de acadêmicos de enfermagem sobre avaliação e tratamento de feridas. Rev Enferm Atenção Saúde.2015;4(1):2-15.

17. Simão CMF, Caliri MHL, Santos CB. Concordância entre enfermeiros quanto ao risco dos pacientes para úlcera por pressão. Acta Paul Enferm. 2013;26(1):30-5. https://doi. org/10.1590/S0103-21002013000100006

18. Harries RL, Bosanquet DC, Harding KG. Wound bed preparation: TIME for an update. Int Wound J. 2016;13(S3):814. https://doi.org/10.1111/iwj.12662 